\title{
PENGARUH KETEBALAN DINDING TERHADAP TIME LAG MASJID JAMI' KOTA PALOPO
}

\author{
Amru Siola \\ Prodi Arsitektur, Fakultas Teknik, Universitas Ichsan Gorontalo
}

\begin{abstract}
Abstrak
Penelitian ini bertujuan mengetahui pengaruh ketebalan dinding terhadap lingkungan termal masjid Jami' Palopo, dengan cara: Bagaimana pengaruh ketebalan dinding terhadap perbedaan temperatur permukaan dinding luar dengan temperatur permukaan dinding dalam, dan kecepatan pelepasan panas (time lag)?. Metode yang digunakan pada penelitian ini adalah: observasi lapangan menggunakan alat untuk mengukur temperatur permukaan dinding dalam dan luar, pergerakan udara, temperatur bukaan, kelembaban dan temperatur lingkungan. Hasil pengukuran dijabarkan dalam bentuk grafik dan dijelaskan secara deskriptif, kemudian dianalisis pada program komputer dengan metode simulasi. Hasil penelitian menunjukkan bahwa antara temperatur ruang shalat dengan temperatur lingkungan bangunan sangat nyata. Analisis simulasi dengan variasi ketebalan dinding batu alam. Jadi time lag yang dihasilkan sebesar 11 jam. Sedangkan untuk ketebalan dinding $92 \mathrm{~cm}$ dan $100 \mathrm{~cm}$ pada pukul 19:00 sampai pukul 06:00 hasilnya positif, dan pada pukul 07:00 sampai pukul 18:00, temperatur yang dilepaskan hasilnya negatif, maka time lag yang dihasilkan adalah 12 jam.
\end{abstract}

Kata kunci: Masjid Jami’, Termal Lingkungan, Time Lag, Dinding Batu

\begin{abstract}
This study aims to know the influence of the thickness of a wall to the environment thermal masjid as? palopo, by: how the influence of the thickness of a wall to a difference in temperature a wall surface the outside with the surface temperatures of a wall in, and speed dissipation of heat (time lag ) ?. Methods used to research is: observation the field uses a tool for measures temperature a wall surface inside and outside of , the movement of air, temperature openings, humidity and ambient temperature. The measurement result outlined in graphical form and described a sort of descriptive set, then analyzed on a computer program with the methods simulation. The research results show that between temperature space prayer with ambient temperature building very real.Analysis simulations with variation the thickness of a wall natural stone. So time lag resulting from 11 hours. While for the thickness of a wall $92 \mathrm{~cm}$ and $100 \mathrm{~cm}$ at 19: 00 to at 6:00 positive result,
\end{abstract}

\section{PENDAHULUAN}

Indonesia yang terletak pada kawasan beriklim tropis lembab, dengan suhu rata-rata tahunan tidak pernah di bawah $23^{\circ} \mathrm{C}$, panas adalah masalah utama yang harus di hadapi, artinya bangunan di Indonesia umumnya harus dapat membuat pemakainya tetap dingin. Untuk itu yang harus diperhatikan adalah selubung bangunan yang dimana berperan sebagai alat untuk memanipulasi iklim kondisi iklim setempat agar tercapai kenyamanan termal bagi manusia dalam melakukan aktivitas dalam suatu bangunan.

Dinding merupakan elemen bangunan yang diharapkan dapat merespon faktor iklim dan lingkungan, sebagai alat untuk memanipulasi iklim mikro lingkungan sehingga tercipta iklim mikro di dalam bangunan yang lebih baik. Satu cara untuk memanipulasi iklim mikro lingkungan melalui dinding bangunan adalah dengan menentukan pemilihan material dindingnya, ketebalan dinding, warna dinding, juga time lag. Kombinasi secara tepat variabel-variabel tersebut dapat menciptakan kenyamanan termal di dalam bangunan. Tetapi pada umumnya, dinding sebagai fasade bangunan cenderung dirancang untuk memenuhi nilai estetis dibandingkan sebagai alat memanipulasi kondisi iklim.

Dari segi arkeologis, masjid Tua Jami' Palopo memberikan gambaran tentang pola permukiman Islam pada masa itu dimana keterkaitan antara masjid, alun-alun dan istana sangat erat. Bentuk serta massa sebagai pusat orientasinya. Francois and Auguste (1983) dalam Rahim and Anwar (2007) mengatakan bahwa karakter yang mendasari kotakota Islam adalah adanya pandangan terhadap aspek privasi, karena di dalam agama Islam aspek privasi merupakan salah satu hal penting dalam kehidupan. Oleh karenanya masjid merupakan simbol dari suatu komunitas masyarakat yang mempercayai keberadaanya sebagai faktor pemersatu masyarakat dan berperan pula sebagai katalisator dalam pembangunan pengembangan masyarakat. Secara 
fisik Masjid Jami' Tua Palopo mempunyai bentuk bangunan yang tidak berbeda jauh dengan masjidmasjid tua yang ada di Jawa dan Masjid Tua yang ada di Sulawesi.

Konstruksi Masjid Jami' Tua Palopo sangat unik, kemungkinan besar hanya satu-satunya di Indonesia dan juga di dunia. Keunikan masjid ini pada bentuk dan konstruksi dinding terbuat dari batu alam (cadas) yang dibentuk menjadi balok-balok segi empat yang tebal $92 \mathrm{~cm}$ ) dan dapat dipastikan mendapat pengaruh arsitektur candi di Jawa. Pengaruh arsitektur candi baik Budha maupun Hindu juga terlihat pada denahnya yang bujur sangkar, dalam hal ini luas lantainya 13 x $13 \mathrm{~m}$. Hiasan bagian bawah dinding tebal (subbase) tersebut berupa molding penyerdehanaan bagian bunga padmanaba (lotus) sama dengan yang ada di Candi Borobudur. Alur-alur di bagian atas dinding juga sama dengan hiasan pada candi-candi di Jawa, Sumalyo (2000), yang menarik dari konstruksi ini adalah bahwa digunakannya konstruksi dinding batu alam yang tebal, yang sesungguhnya merupakan karakteristik bangunan beriklim moderat (dingin). Sehingga menarik untuk diketahui apakah dengan material dinding dengan menggunakan batu alam dengan konstruksi tebal $92 \mathrm{~cm}$, apakah dinding masjid dapat memberikan pengaruh terhadap kondisi termal di dalam bangunan (memberikan kenyamanan termal). Banyaknya bukaan dinding pada Masjid Tua Jami' Palopo (jendela dan ventilasi) yang merupakan filosofi rukun Islam dan rukun iman. Bersama dengan dinding dengan bukaan yang ada, suatu hal yang menarik untuk di teliti apakah dengan konstruksi dinding yang tebal dan bukaan dinding memberikan pengaruh terhadap kondisi termal di dalam bangunan (ruang shalat).

Fokus penelitian adalah pada masalah termal, yang berkaitan dengan pengaruh ketebalan dinding terhadap lingkungan termal masjid, sehingga dapat diketahui sejauh mana pengaruh dinding terhadap pelepasan panas ke dalam ruang.

\section{ISI PENELITIAN}

Bagian ini dapat dibagi dalam beberapa sub pokok pembahasan sesuai dengan kebutuhan tulisan. Tidak ada batasan yang baku mengenai jumlah pemerincian sub pokok bahasannya, tetapi setidaknya mengandung: metode, hasil, dan pembahasan.

\subsection{Metode}

Penelitian digunakan metode tertentu. Metode yang digunakan dalam penelitian ini adalah metode penelitian kuantitatif, yaitu observasi lapangan dengan menggunakan alat ukur, kemudian dijabarkan dalam bentuk grafik yang akan diperbandingkan dan dijelaskan secara deskriptif, juga membandingkan dengan data statistik kemudian dianalisis pada program komputer dengan metode simulasi. Dan juga dengan melakukan pengamatan lapangan dan perhitungan model simulasi.
Pengamatan lapangan untuk mendapatkan data lapangan saat itu, sedangkan simulasi untuk memprediksi pengaruh ketebalan dinding dengan beberapa variasi ketebalan dinding. Perhitungan temperatur luar dan dalam dilakukan dengan model simulasi. Hasil pengkuran temperatur lapangan, berupa temperatur rata-rata luar dan dalam yang dapat dianggap mewakili bulan pengamatan tersebut.

\subsection{Hasil}

\subsubsection{Alat Penelitian}

Alat pengukuran untuk data primer yang digunakan adalah:

a. Alat sketsa, alat perekam visual berupa kamera; Merk: Canon seri 5000, untuk menjelaskan kondisi obyek penelitian.

b. TERMOKOPEL merupakan alat untuk mengukur suhu ruangan dan temperatur ketebalan dinding, Termocoupel Meter Type Double Ways VA 8060, dengan tampilan digital.

c. Anemometer Hot Wire, merupakan alat pengukur pergerakan udara yang sangat lemah/perlahan, merk Lutron AM.4204.

d. Temperature and Humidity Meter merupakan alat untuk mengukur temperatur lingkungan dan kelembaban lingkungan, merk Krisbow KW06797.

e. Alat ukur jarak berupa meteran gedung untuk mengukur luas bangunan dan jarak antara lantai dengan posisi alat dengan media yang diukur (dinding).

2.2.2 Lokasi dan Waktu Penelitian

Lokasi penelitian di wilayah Sulawesi Selatan bagian Utara tepatnya di wilayah administratif Kelurahan Batu Pasi Kecamatan Wara Utara Kota Palopo. Kota Palopo berada 390 km di sebelah utara Kota Makassar. Lokasi di fokuskan pada salah satu masjid bersejarah yaitu Mesjid Tua Palopo atau Mesjid Jami' Palopo yang peninggalan Kerajaan Luwu berada di kota Palopo, Sulawesi Selatan. Masjid ini didirikan pada masa pemerintahan Raja Luwu yang bernama Datu Payung Luwu XVI Pati Pasaung Toampanangi Sultan Abdullah Matinroe dan di pandu oleh ahli bangunan berkebangsaan

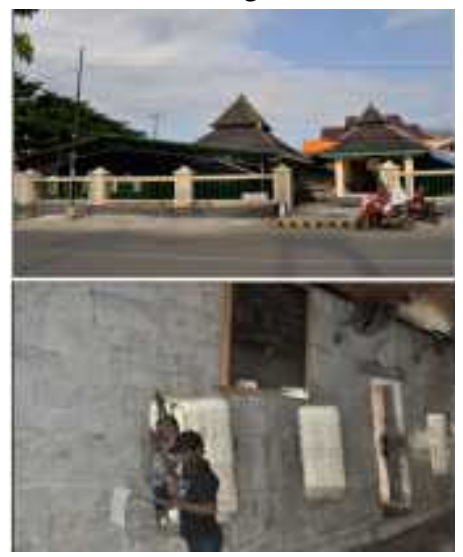

Gambar 1 : (a) Situasi Mesjid Jami', (b) Foto Saat Pengukuran dengan alat Termokopel 
Vietnam pada masa itu bernama Fung Mun Te tahun $1604 \mathrm{M}$ dan memiliki ukuran pada ruang shalat 13 x $13 \mathrm{~m}$. Kedua makna ini memiliki relasi dengan proses pembangunan Masjid Tua Palopo ini.

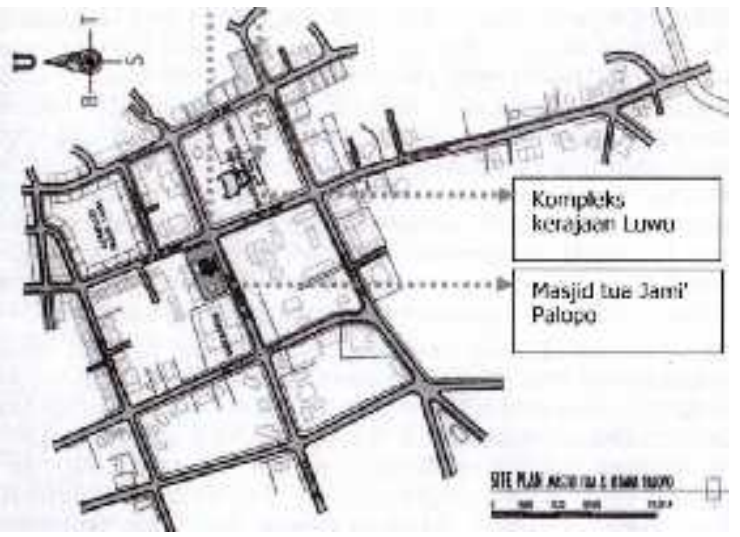

Gambar 2 : Site Plan Masjid Jami' Palopo dan Kompleks Istana Datu (Raja) Luwu, sumber: Rahim dan Anwar (2007)

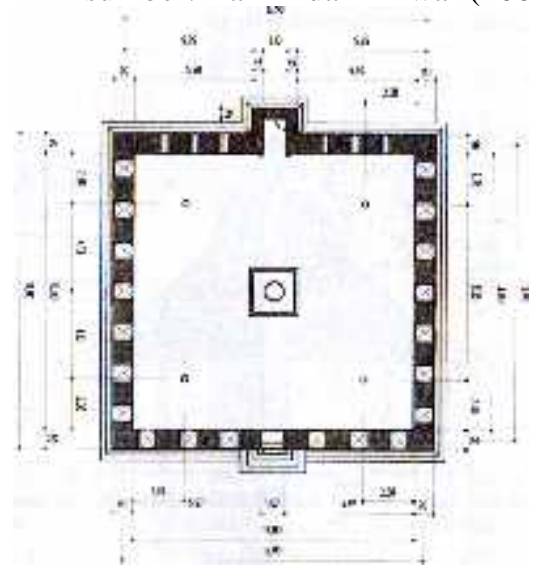

Gambar 3 : Denah Masjid Jami' Palopo dan Kompleks Istana Datu (Raja) Luwu, sumber: Rahim dan Anwar (2007)

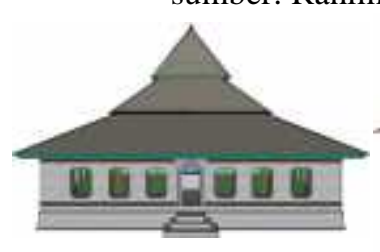

(a)

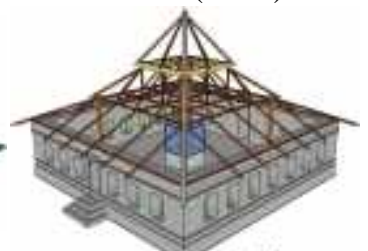

(b)

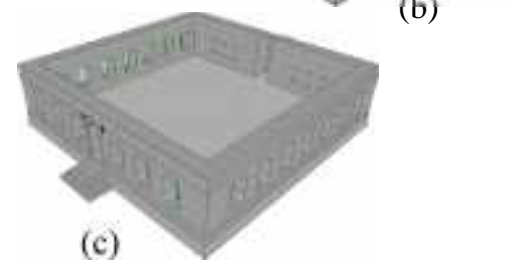

(c)

Gambar 3: (a) Tampak Masjid Jami' Palopo (b) Tampak Presfektif Struktur Masjid Jami’ Palopo, (c) Tampak Dinding (tebal dinding $92 \mathrm{~cm}$ ) Masjid Jami' Palopo, sumber: hasil olahan software SketchUp oleh peniliti (2014).

2.2.3 Populasi dan Teknik Sampel

Guna mengetahui time lag terhadap pengaruh dinding dan bukaan dinding pada Masjid Jami' Palopo, dilakukan pengukuran temperatur permukaan dinding dalam dan luar. Pengukuran dilakukan pada orientasi Barat, Utara, Timur, dan Selatan bangunan. Masing-masing dinding (tidak termasuk bukaan) terdapat 12 titik pengukuran, yaitu 6 pada permukaan luar dan 6 pada permukaan dalam dan luar, sehingga total terdapat 48 titik pengukuran. Untuk pengukuran data-data temperatur udara (temperatur kering), kelembaban udara, dan pergerakan udara dilakukan pada 5 titik pengukuran pada lingkungan dan 1 titik pengukuran di dalam ruangan. Untuk data-data temperatur permukaan dinding, akan dilakukan pada sisi Barat, Utara, Timur, dan Selatan. Terdapat 12 titik pengukuran untuk tiap orientasi fasade (total 48 tititk pengukuran permukaan dinding). Dan pada saat pengukuran kipas angin, lampu (bola lampu) dalam keadaan off. 2.2.4 Titik Pengukuran Temperatur Dinding

Terdapat 48 titik pengukuran permukaan dinding, 1 pintu, dan 6 jendela pada dinding barat. Sedangkan pada dinding utara dan selatan terdapat 7 jendela, sisi timur 12 hanya sebagai ventilasi udara terdiri atas 12 titik pengukuran, yang terdiri dari 6 titik pada sisi luar dinding dan 6 titik pada sisi dalam dinding.

Untuk titik pengukuran dinding sisi dalam tetap sama, tetapi dengan notasi 1' untuk dinding bagian dalam dan untuk notasi 1 untuk dinding bagian luar dan seterusnya. Untuk membedakan antara orientasi dinding yang satu dengan dinding yang lain akan digunakan notasi $\mathrm{U}$ untuk dinding Utara, notasi $\mathrm{T}$ untuk dinding bagian Timur, notasi $\mathrm{S}$ untuk dinding bagian Selatan dan notasi B untuk dinding bagian Barat. Data yang di cari pada pengukuran ini adalah temperatur permukaan dinding untuk tiap pengukuran (gambar 4 dan gambar 5) dengan alat ukur Termokopel type T.

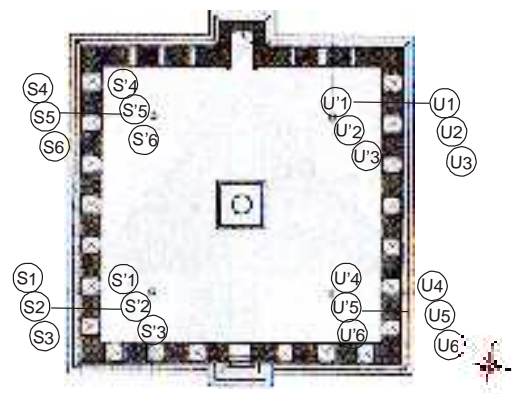

Gambar 4: Titik-titik pengukuran dinding Utara dan Selatan (Data temperatur permukaan dinding)

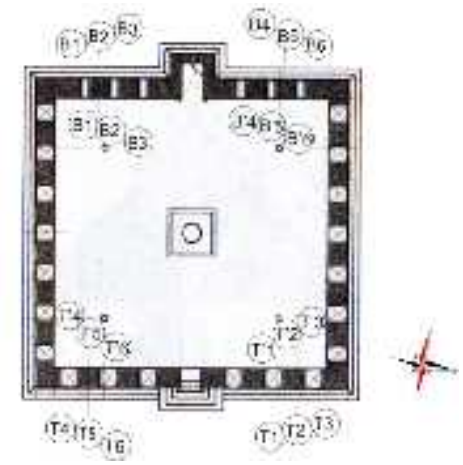


Gambar 5: Titik-titik pengukuran dinding Timur dan Barat (Data temperatur permukaan dinding) Sumber : Peniliti, (2014)

Data kuantitatif temperatur udara diukur menggunakan Termokopel untuk mendapatkan temperatur di dalam bangunan, temperatur pada samping masjid, dan temperatur pada lingkungan. Sedangkan untuk mendapatkan data ukur tentang pergerakan udara di dalam bangunan dan luar bangunan menggunakan Anemometer Hot Wire. Selain itu akan dilakukan pengukuran untuk mendapatkan data kelembaban udara dan pergerakan angin di lapangan, sedangkan data dari Badan Meteorologi merupakan sebagai data penunjang. Dan kemudian data yang didapatkan didistribusikan kedalam bentuk tabel, yang kemudian di jadikan data kondisi aktual pada proses simulasi dengan menggunakan software Autodesk Ecotect 2011.

\subsection{Pembahasan}

Analisa dilakukan dengan mengkaji pengaruh ketebalan dinding dan luas bukaan terhadap kondisi termal pada bangunan mesjid tua Jami' Palopo. Setelah data-data dikumpulkan kemudian dilakukan kompilasi data. Temuan-temuan yang didapat dari observasi lapangan langsung untuk mendapatkan data kuantitatif. Kemudian temuan-temuan ini dikaji dengan menggunakan teknik eksplanasi, yakni menjelaskan hasil data yang di dapat untuk dikonfirmasikan dengan teori-teori yang terkait serta memperbandingkan dengan penelitian sejenis.

\subsubsection{Deskripsi Hasil Penelitian}

Pengukuran dilakukan selama 14 (empat belas) hari pada bulan Mei dan bulan agustus, tepatnya pada tanggal 18 Mei 2014 sampai dengan tanggal 31 Mei 2014 Di mulai pada jam 07.00 pagi hingga jam 19.00 sore WITA dan tanggal 23 Agustus 2014 sampai tanggal 27 Agustus 2014. Di mulai pada jam 00.00 pagi hingga jam 23.00 malam WITA.

Pengukuran dilakukan setiap selang 2 jam pada bulan Mei dan selang 1 jam pada bulan Agustuss dengan titik pengukuran yang sudah dijelaskan, dan target data:

- Temperatur udara $(d b t)$

- Kelembaban udara rata-rata

- Pergerakan udara (angin)

- Temperatur permukaan dinding

Secara umum kondisi cuaca berubah-ubah selama pengukuran di laksanakan yaitu: cerah, berawan dan kadang hujan gerimis.

\subsubsection{Pembayangan Fasade}

Hampir sepanjang hari seluruh fasade bangunan terlindungi dari sinar matahari. Hanya fasade utara dan barat yang terkena sinar matahari meskipun hanya untuk waktu yang terbatas. Fasade utara terkena sinar matahari sekitar jam 06:30. Pada waktu pengukuran jam 07:00, terjadi pembayangan mulai ketinggian $50 \mathrm{~cm}$ dari muka lantai disamping bangunan bagian Utara, dan sedangkan fasade Timur tertutup seluruhnya oleh atap serambi depan masjid.
Fasade Barat terkena sinar matahari mulai sekitar jam 14:00, pada waktu pengukuran jam 15:00, terjadi pembayangan mulai ketinggian $50-120 \mathrm{~cm}$ dari muka lantai (muka pondasi luar) Barat, dan pada pengukuran jam 17:00 seluruh fasade Barat telah terbayangi seluruhnya oleh atap halaman belakang.

\subsubsection{Temperatur Permukaan Dinding}

Secara umum hampir tidak ada perbedaan temperatur permukaan dinding luar dan permukaan dinding dalam. Begitu pula dengan perbedaan ketinggian titik pengukuran, tidak ada perbedaan pada ketinggian $20 \mathrm{~cm}$ dari lantai, $120 \mathrm{~cm}$ dan 300 $\mathrm{cm}$. Juga untuk perbedaan titik pengukuran secara horizontal (sisi kiri fasade dan sisi kanan fasade). Meskipun demikian tetap terjadi perbedaan waktu pengukuran tertentu dan pada titik pengukuran tertentu.

2.3.5 Analisis Perbedaan Temperatur Permukaan Dinding Luar dengan Dinding Dalam

Tabel 1: Hasil Pengukuran Temeperatur dengan Termokopel

$\begin{array}{ll}\text { Hari } & : \text { Minggu } \\ \text { Tanggal } & : 25 \text { Mei } 2014\end{array}$

\begin{tabular}{|c|c|c|c|c|c|c|}
\hline \multirow{2}{*}{$\begin{array}{l}\text { Titik } \\
\text { Ukur }\end{array}$} & \multicolumn{6}{|c|}{$\begin{array}{l}\text { Selisih Temperatur Permukaan Dinding } \\
\qquad\left({ }^{\circ} \mathrm{C}\right)\end{array}$} \\
\hline & $\begin{array}{l}\text { U1 - } \\
\text { U'1 }\end{array}$ & $\begin{array}{c}\mathrm{U} 2 \\
-\mathrm{U}^{\prime} 2 \\
\end{array}$ & $\begin{array}{l}\text { U3 - } \\
\text { U'3 }\end{array}$ & $\begin{array}{l}\mathrm{U} 4 \text { - } \\
\mathrm{U} 4\end{array}$ & $\begin{array}{l}\text { U5 - } \\
\text { U.5 }\end{array}$ & $\begin{array}{l}\text { U6 - } \\
\text { U'6 }\end{array}$ \\
\hline 07:00 & 0.8 & 0.5 & 0.1 & 0.2 & 0.1 & 0.2 \\
\hline 09:00 & 0.1 & 1.1 & 0.2 & 0.4 & 1.1 & 0.8 \\
\hline 11:00 & 0.3 & 0.1 & 0.6 & -0.5 & 0.0 & 0.1 \\
\hline 13:00 & 0.1 & 0.1 & 0.1 & 0.0 & 0.0 & 0.1 \\
\hline 15:00 & 1.5 & 3.6 & 0.6 & 1.8 & 2.4 & 0.8 \\
\hline 17:00 & 0.1 & 0.1 & 0.3 & 0.2 & 0.1 & 0.5 \\
\hline $\begin{array}{c}\text { rata- } \\
\text { rata }\end{array}$ & 0.5 & 0.9 & 0.3 & 0.4 & 0.6 & 0.4 \\
\hline
\end{tabular}

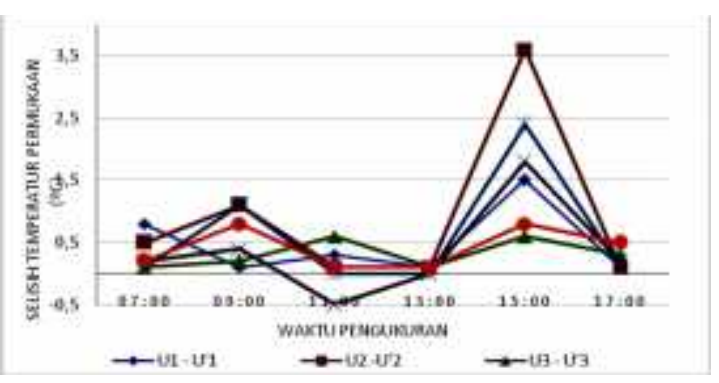

Gambar 6: Kurva hasil pengukuran perbedaan temperatur permukaan dinding luar dengan dinding dalam (fasade utara)

Pada jam 7.00 perbedaan temperatur permukaan dinding luar dengan dalam pada posisi U2-U'2' dan U5-U'5 (2 dan 5 berada pada $1.2 \mathrm{~m}$ diatas lantai, sedangkan U3-U'3 dan U6-U'6 (berada pada $3 \mathrm{~m}$ di 
atas lantai) sangat kecil perbedaannya hal ini disebabkan permukaan dinding luar belum terpengaruh oleh peningkatan temperatur lingkungan dan radiasi malahari sehingga memiliki temperatur permukaan yang lebih kecil dengan dinding dalam. Sedangkan pada jam 15.00 pada posisi U1-U'1, U2U'2, U4-U'4 dan U5-U'5 dinding telah terkena radiasi matahari langsung sehingga permukaan dinding luar jauh lebih panas dibandingkan permukaan dinding dalam. Bila dianalisis secara keseluruhan (seluruh dinding fasade Utara), maka perbedaan temperatur permukaan dinding luar dengan dinding dalam terbesar terjadi pada jam 15:00, matahari berada pada posisi tertinggi sehingga mempunyai tingkat radiasi yang tinggi yang mengakibatkan lingkungan menjadi panas, dan kemudian setelah jam 15.00 menurun. Secara keseluruhan, rata-rata perbedaan temperatur permukaan dinding luar dengan dalam untuk dinding utara adalah $0.517^{\circ} \mathrm{C}$.

Tabel 2: Selisih Temperatur Permukaan Dinding Timur

\begin{tabular}{|c|c|c|c|c|c|c|}
\hline \multirow{3}{*}{$\begin{array}{l} \\
\text { Titik } \\
\text { Ukur }\end{array}$} & \multicolumn{2}{|c|}{$\begin{array}{l}\text { Hari } \\
\text { Tanggal }\end{array}$} & \multicolumn{3}{|c|}{ : Minggu } & \\
\hline & \multicolumn{6}{|c|}{ Selisih Temperatur Permukaan Dinding $\left({ }^{\circ} \mathrm{C}\right)$} \\
\hline & $\begin{array}{l}\text { T1 - } \\
\text { T'1 }\end{array}$ & $\begin{array}{l}\mathrm{T} 2- \\
\mathrm{T} 2\end{array}$ & $\begin{array}{l}\text { T3 - } \\
\text { T'3 }\end{array}$ & $\begin{array}{c}\mathrm{T} 4 \text { - } \\
\mathrm{T} 4 \\
\end{array}$ & $\begin{array}{l}\mathrm{T} 5- \\
\mathrm{T} 5\end{array}$ & $\begin{array}{l}\text { T6 - } \\
\text { T'6 }\end{array}$ \\
\hline $\begin{array}{c}\text { 07:0 } \\
\text { 0 }\end{array}$ & 0.0 & 0.0 & 0.0 & 0.3 & 0.2 & -0.1 \\
\hline $\begin{array}{c}\text { 09:0 } \\
0\end{array}$ & 0.4 & -0.4 & -0.1 & 0.1 & 0.4 & 0.7 \\
\hline $\begin{array}{c}\text { 11:0 } \\
0\end{array}$ & 0.1 & 0.3 & 0.1 & 0.5 & 0.3 & 0.3 \\
\hline $\begin{array}{c}13: 0 \\
0\end{array}$ & 0.4 & 0.4 & 0.2 & 0.6 & 0.3 & 0.2 \\
\hline $\begin{array}{c}15: 0 \\
0\end{array}$ & -0.4 & 0.1 & -0.3 & -0.3 & 0.1 & -0.1 \\
\hline $\begin{array}{c}17: 0 \\
0\end{array}$ & 0.2 & 0.4 & 0.3 & 0.7 & 0.3 & 0.1 \\
\hline $\begin{array}{l}\text { rata- } \\
\text { rata }\end{array}$ & 0.1 & 0.1 & 0.0 & 0.3 & 0.3 & 0.2 \\
\hline
\end{tabular}

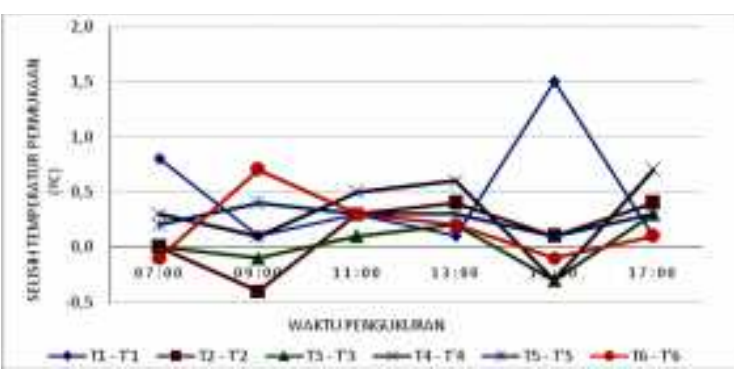

Gambar 8: Kurva hasil perbedaan temperatur permukaan dinding Iuar dengan dinding dalam (fasade timur)

Tanda negatif pada tabel 18 (jam 9:00 dan 15:00) menunjukkan bahwa temperatur permukaan dinding dalam lebih tinggi dari temperatur permukaan dinding Iuar (temperatur permukaan dinding Iuar T2 adalah $27.5^{\circ} \mathrm{C}$ sedangkan temperatur permukaan dinding dalam T'2 adalah $27.9^{\circ} \mathrm{C}$ ). Pada jam 15.00 titik ukur T1-T'1 $\left(29.9^{\circ} \mathrm{C}-30.3^{\circ} \mathrm{C}\right)$. Kondisi ini terjadi karena dinding Iuar telah mengalami pendinginan oleh udara malam dari lingkungan yang mempunyai temperatur lebih rendah dari pada di dalam bangunan. Sedangkan dinding dalam diperkirakan masih dalam proses pendinginan setelah tercapai puncak time lag pada malam hari.

Analasis berdasarkan ketinggian titik ukur dari muka lantai menunjukkan bahwa posisi ketinggian tidak memberikan pengaruh kepada rata-rata perbedaan temperatur permukaan dinding luar dengan dinding dalam. Hal ini terjadi karena pada fasade Timur yang mempengaruhi temperatur permukaan hanya kondisi lingkungan serambi, sehingga memberikan pengaruh panas pada dinding luar secara relatif sama pada semua posisi pengukuran.

Perbedaan temperatur permukaan dinding luar dengan dalam meningkat seiring dengan meningkatnya temperatur lingkungan sebagai akibat akumulasi panas lingkungan dan radiasi matahari. Bila dianalisis secara keseluruhan (seluruh dinding fasade timur), rnaka perbedaan temperatur permukaan dinding luar dengan dinding dalam terbesar terjadi pada jam 09:00 yaitu sebesar $0.7^{\circ} \mathrm{C}$ yang kemudian turun menjadi $0.1^{\circ} \mathrm{C}$ pada jam 17.00 bersamaan dengan semakin rendahnya posisi matahari. Dengan rendahnya posisi matahari menyebabkan sisi Timur bangunan (masjid) menjadi daerah bayangan, yang menyebabkan temperatur lingkungan ikut menjadi rendah.

Secara keseluruhan, rata-rata perbedaan temperatur permukaan dinding luar dengan dalam untuk dinding Timur adalah $0,175^{\circ} \mathrm{C}$.

Tabel 3: Selisih Temperatur Permukaan Dinding

$$
\begin{array}{ll}
\text { Hari } & : \text { Minggu } \\
\text { Tanggal } & : 25 \text { Mei } 2014
\end{array}
$$

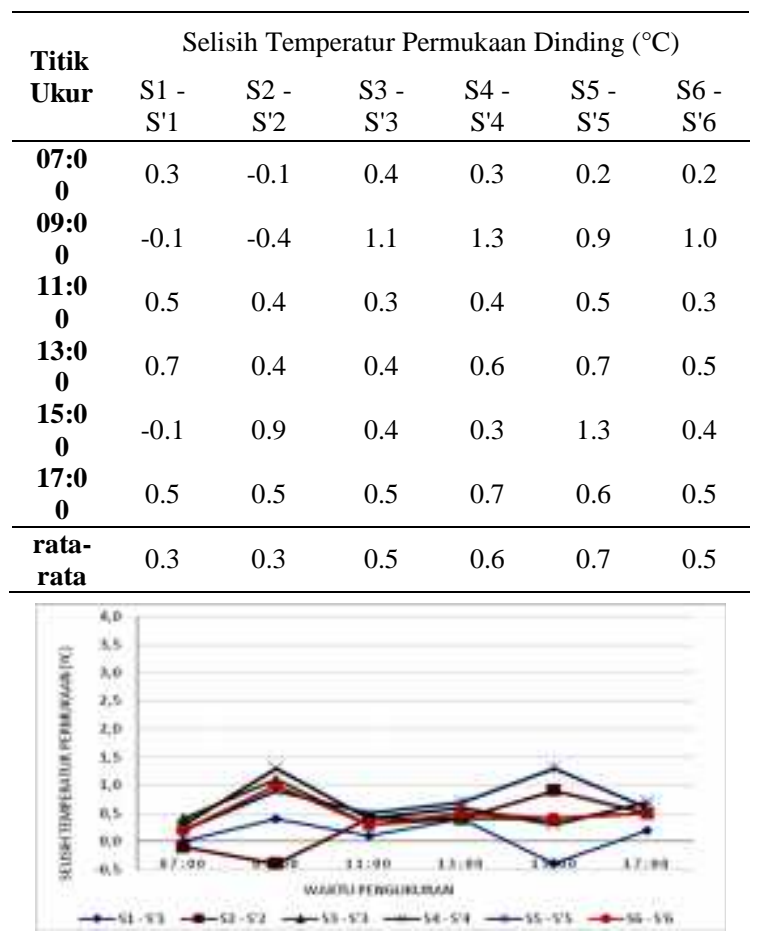


Gambar 9: Kurva hasil perbedaan temperatur permukaan dinding luar dengan dinding dalam (fasade Selatan) Tanda negatif pada tabel 19 (jam 07:00, 09:00 dan 15:00) menunjukan bahwa temperatur permukaan dinding dalam lebih tinggi dari temperatur permukaan dinding luar (temperatur permukaan dinding luar adalah $30^{\circ} \mathrm{C}$ sedangkan temperatur permukaan dinding dalam adalah $31^{\circ} \mathrm{C}$ ). Perbedaan temperatur permukaan dinding luar dengan dalam tidak terlalu drastis $\left(-0.1^{\circ} \mathrm{C}\right)$ dan pada jam 09.00 perbedaan temperatur permukaan dinding naik menjadi $\left(-0.4^{\circ} \mathrm{C}\right)$ bersamaan meningkatnya temperatur lingkungan. Perbedaan temperatur permukaan dinding luar dengan dalam kemudian menjadi $0.5^{\circ} \mathrm{C}-0.7^{\circ} \mathrm{C}$ pada jam 17.00 , dimana temperatur dinding dalam menjadi turun sehingga sedangkan temperatur permukaan dinding luar menjadi naik. Penurunan temperatur permukaan disebabkan setelah jam 12.00 matahari relatif berada pada sisi Utara bangunan sehingga sisi Selatan mulai mendapat pembayangan dari bangunan masjid itu sendiri. Dan juga pada jam 17.00, perbedaan temperatur permukaan kembali meningkat menjadi $0.5^{\circ} \mathrm{C}-0.7^{\circ} \mathrm{C}$.

Terjadinya perbedaan temperatur permukaan berdasarkan ketinggian posisi titik ukur pada jam 15.00 disebabkan pada temperatur permukaan dinding luar dengan posisi titik ukur yang lebih tinggi mengalami peningkatan. Peningkatan temperatur ini dipengaruhi oleh panas dari atap, sedangkan pada ketinggian yang lebih rendah masih belum terpengaruh.

Baru nanti pada jam 17.00 temperatur permukaan dinding pada posisi ' 1 ' dan ' 5 ' ikut meningkat. Secara keseluruhan, rata-rata perbedaan temperatur permukaan dinding luar dengan dalam untuk dinding selalan adalah $0,481^{\circ} \mathrm{C}$.

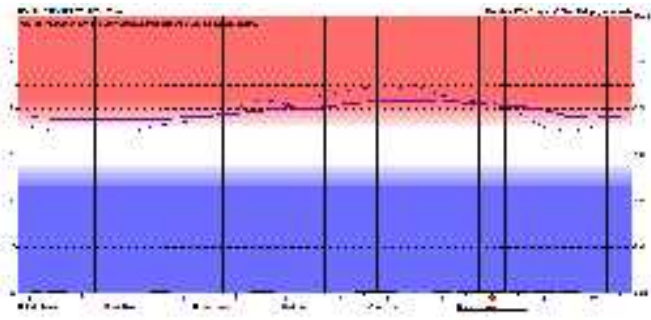

Gambar 10: Grafik kenyamanan termal tebal dinding $100 \mathrm{~cm}$, sumber: analisis simulasi ecotect

Tabel 4: Hasil Analisis Kenyamanan Termal Tebal Dinding $100 \mathrm{~cm}$. sumber: analisis simulasi ecotect

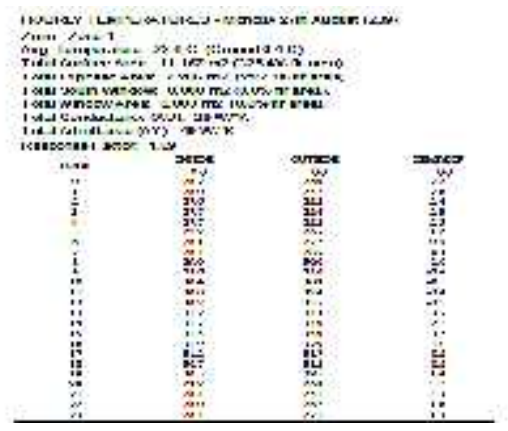

Analisis simulasi ecotect pada gambar 86, menunjukkan bahwa zona nyaman pada jam 00.00 sampai dengan jam 06.00 dan jam 19.00 sampai jam 23.00, sedangkan temperatur maximum dalam ruangan $31,9^{\circ} \mathrm{C}$ pada jam 16.00 dan temperatur minimum pada jam 02.00 yaitu $27,6^{\circ} \mathrm{C}$ sedangkan pelepasan panas sebesar $29 \mathrm{~W} /{ }^{\circ} \mathrm{K}$, dan daya tahan termal (admittance) $49 \mathrm{~W} /{ }^{\circ} \mathrm{K}$ dengan ketebalan dinding $100 \mathrm{~cm}$.

Tebal dinding $110 \mathrm{~cm}$

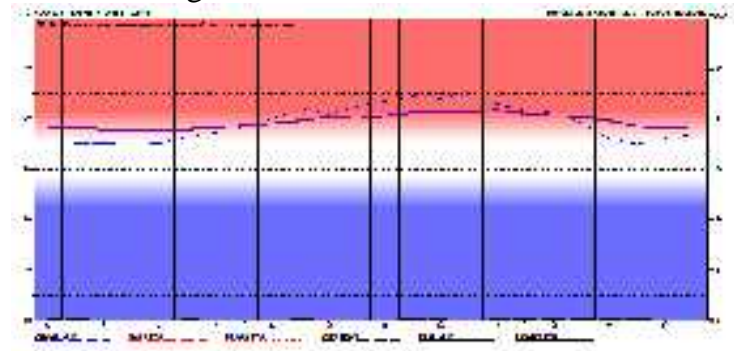

Gambar 11: Grafik kenyamanan termal tebal dinding $110 \mathrm{~cm}$, sumber: analisis simulasi ecotect

Tabel 5: Hasil analisis kenyamanan termal tebal dinding $110 \mathrm{~cm}$. sumber: analisis simulasi ecotect

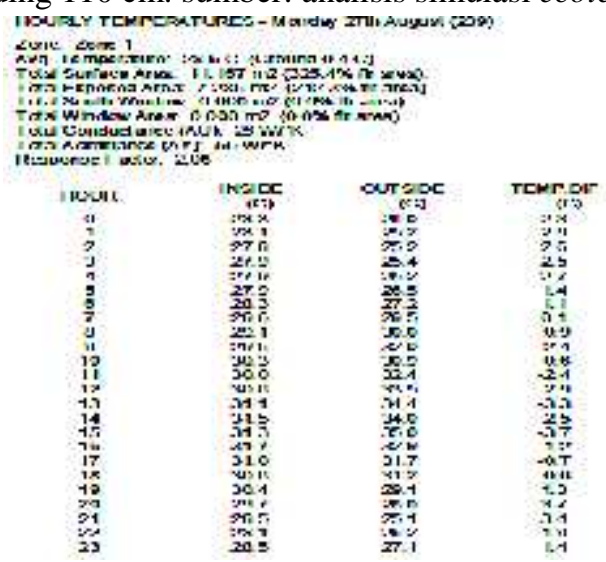

Analisis simulasi ecotect pada gambar 87, menunjukkan bahwa zona nyaman pada jam 00.00 sampai dengan jam 07.00 dan jam 19.00 sampai jam 23.00, sedangkan temperatur maximum dalam ruangan $31,7^{\circ} \mathrm{C}$ pada jam 16.00 dan temperatur minimum pada jam 02.00 yaitu $27,8^{\circ} \mathrm{C}$ sedangkan pelepasan panas sebesar $29 \mathrm{~W} /{ }^{\circ} \mathrm{K}$, dan daya tahan termal (admittance) $49 \mathrm{~W} /{ }^{\circ} \mathrm{K}$ dengan ketebalan dinding $110 \mathrm{~cm}$.

Time lag suatu dinding ditentukan berdasarkan waktu yang dibutuhkan oleh dinding dalam untuk mempunyai temperatur yang sama dengan temperatur maksimal dinding luar. Berdasarkan data pada tabel 10,11, 12, dan 13, maka terlihat bahwa besarnya temperatur maksimal permukaan dinding luar berbeda-beda untuk tiap arah orientasi dinding. Temperatur permukaan dinding luar paling tinggi adalah $32^{\circ} \mathrm{C}$ untuk fasade Barat, sedangkan temperatur permukaan dinding dalam paling dibawah adalah $30.4^{\circ} \mathrm{C}$ (sampai pengukuran jam 15.00). Analisis Time Lag 


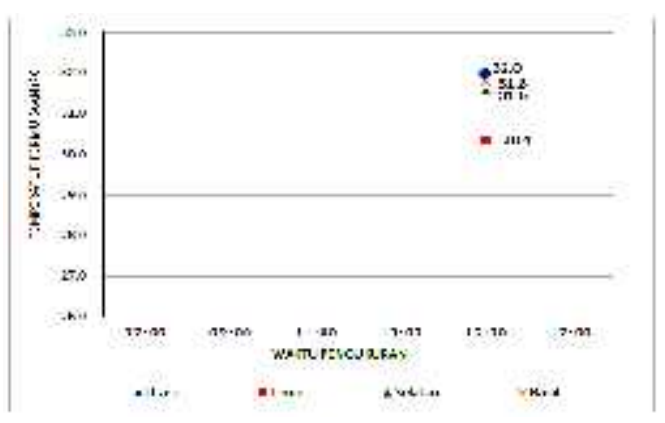

Gambar 12: Kurva hasil pengukuran tanggal 25 mei 2014 untuk temperatur maksimal permukaan dinding luar.

Hal ini berarti selama 10 jam (dari jam 7.00 sampai jam 17.00) waktu pengukuran temperatur maksimal permukaan dinding dalam belum sama dengan temperatur maksimal dinding luar. Dengan demikian bisa dikatakan bahwa time lag dari dinding masjid adalah lebih dari 10 jam. Tetapi bila waktu tercapainya time lag pada dinding (yaitu jam 11.00 untuk dinding selatan) yang dipakai sebagai acuan, maka time lag dinding adalah lebih dari 6 jam (dari jam 11.00 sampai 17.00). Sebagai perbandingan bahwa standar time lag untuk batu alam dengan 20 $\mathrm{cm}=5,5 \mathrm{jam}, 30 \mathrm{~cm}=8,5$ jam, $40 \mathrm{~cm}=10,5$ jam dan ketebalan $60 \mathrm{~cm}$ adalah 15,5 jam; Lippsmeier,(1980). Jadi apabila di asumsikan pada tabel 3, maka setiap tebal $10 \mathrm{~cm}$ time lag (pergeseran waktu jam) sebesar 2,5 jam, jadi time lag pada batu alam dengan tebal dinding $92 \mathrm{~cm}$ sebesar 23,25 jam.

Tabel 6: Time lag Bahan Batu Alam Pada Dinding Masjid Jami’ Palopo

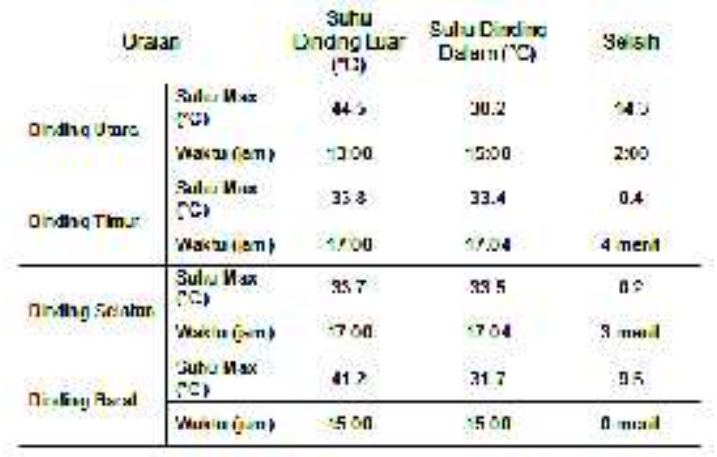

Dari hasil dari pengukuran pada tanggal $18 \mathrm{Mei}$ 2014, bahwa pada fasade dinding Timur dengan titik ukur '2' pada jam 17:00 menunjukkan suhu maksimum temperatur permukaan dinding luar adalah $33.8{ }^{\circ} \mathrm{C}$, dan untuk suhu maksimum permukaan dinding dalam adalah $33.4{ }^{\circ} \mathrm{C}$ pada jam 17:04 (titik ukur '5'), jadi time lag untuk fasade Timur adalah 4 menit. Untuk fasade selatan pada permukaan dinding luar suhu maksimumnya adalah $33.7^{\circ} \mathrm{C}$ (titik ukur '2'), sedangkan suhu maksimum permukaan dinding dalam 33.5 (titik ukur ' 5 ') pada jam 17:04, maka time lag untuk dinding Selatan 4 menit, dan suhu temperatur lingkungan (ruang shalat) sebesar $31.2^{\circ} \mathrm{C}$.
Fasade barat pengukuran pada tanggal 31 Mei 2014 dimana suhu temperatur permukaan dinding luar $41.2{ }^{\circ} \mathrm{C}$ (titik ukur '4'), suhu permukaan dinding dalam 31.2 (titik ukur '4') pada jam yang sama yaitu 15:00, jadi time lag untuk dinding Barat 0 menit, dan suhu temperatur lingkungan (ruang shalat) sebesar $31.3{ }^{\circ} \mathrm{C}$.

Tabel 7: Time lag Bahan Batu Alam Pada Dinding Masjid Jami' Palopo Dengan Hasil Analisis Ecotect Tanggal 27 Agustus 2014

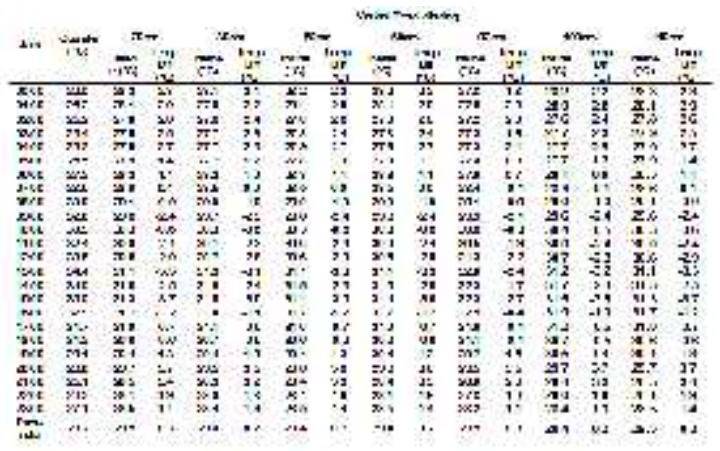

Hasil analisis (tabel 28) simulasi ecotect menunjukkan pada jam 19.00 sampai dengan jam 07.00 temperatur yang dilepaskan hasilnya positif, sedangkan dari jam 08.00 sampai jam 18.00 temperatur yang dilepaskan hasilnya negatif. Jadi pelepasan panas (time lag) rata-rata pada ketebalan dinding $20 \mathrm{~cm}, 30 \mathrm{~cm}, 50 \mathrm{~cm}$, dan 60 adalah 11 jam. Sedangkan hasil analisis simulasi untuk tebal dinding $92 \mathrm{~cm}$ dan $100 \mathrm{~cm}$ masjid Jami' Palopo menujukkan pada 19.00 sampai dengan jam 06.00 temperatur yang dilepaskan hasilnya adalah positif, sedangkan dari jam 07.00 sampai jam 18.00 temperatur yang dilepaskan hasilnya negatif, jadi pelepasan panas (time lag) adalah $12 \mathrm{jam}$.

\section{KESIMPULAN}

Analisis temperatur permukaan dinding menunjukkan bahwa terjadi variasi perbedaan temperatur permukaan dinding luar dengan temperatur permukaan dinding dalam bergantung kepada arah orientasi dinding. Ketebalan dinding dan time lag yang lama menjadi penyebab kondisi ini. Dan hasil simulasi menunjukkan time lag dinding masjid Jami' Palopo adalah 12 jam pada ketebalan dinding $92 \mathrm{~cm}$ sedangkan variasi dinding dengan tebal $50 \mathrm{~cm}$ adalah $11 \mathrm{jam}$. Time lag dinding yang lama adalah hal yang menguntungkan pada bangunan masjid ini, karena hal ini menjadikan kondisi temperatur ruang shalat menjadi relatif tidak panas pada siang hari dimana banyak kegiatan ibadah berlangsung. Sedangkan pelepasan panas pada malam hari tidak merugikan karena pada masa tersebut nyaris tidak ada kegiatan ibadah. Dinding masjid Jami' Palopo mempunyai dua peran. Pertama, ketebalan dan material dinding menyebabkan time lag yang lama sehingga pada siang hari perbedaan temperatur permukaan dinding luar dengan dalam cenderung stabil. Stabilnya 
temperatur permukaan dinding dalam menyebabkan dinding berpengaruh terhadap panas dinding, dan temperatur permukaan dinding tidak selalu meningkat seiring meningkatnya temperatur lingkungan. Kedua, dinding berpengaruh negatif terhadap kondisi termal ruangan, yaitu menghalangi pergerakan udara dari lingkungan ke dalam bangunan.

Penelitian pada Masjid Jami’ Palopo masih dapat diperdalam dengan memfokuskan penelitian saat pemakaian ruang shalat pada waktu shalat dan pemakaian cahaya buatan (elektronik). Karena peneliti ini tidak menguji apakah pemakai bangunan (sementara orang melakukan shalat) merasa nyaman atau tidak. Sehingga penelitian selanjutnya dapat di uji kembali apakah tidak terciptanya kenyamanan termal pada ruang shalat, pada penelitian ini akan sama dengan apa yang di rasakan para pemakai bangunan. Sehingga dapat di ketahui kondisi fisik bangunan atau psikologis pemakai yang menentukan nyaman atau tidaknya ruang shalat Masjid Jami' Palopo.

Pada penelitian ini, jumlah alat ukur yang digunakan sangatlah terbatas sehingga proses pengumpulan data tidak maksimal. Oleh karena itu, perlu adanya penambahan alat ukur seperti mengukur seberapa besar radiasi matahari tiba ke permukaan dinding agar dapat menunjang penelitian-penelitian sejenis. Atau menggunakan alat ukur sekaligus perekam seperti HOBO Dataloger.

\section{DAFTAR PUSTAKA}

Amin, Muhammad (2004), Sensasi Thermal Pada Mesjid Raya Al-Mashun Medan, Universitas Diponegoro, Semarang.

Asih, Dhyan Seminar (2012), Pengaruh Material Pelapis Pada Fasade Bangunan Terhadap Nilai OTTV Studi Kasus: Sekolah Menengah Pertama Negeri di Depok, Universitas Indonesia, Depok.

Egan, M. David (1975) Concept in Thermal Comfort. Prentice-Hall .IncEnglewood Cliffs. New Jersey.

Egan, M. David (1999) Konsep-Konsep Dalam Kenyamanan Termal, Alih Bahasa Srilestari, R.N. Kelompok Sains dan Teknologi Arsitektur, Universitas Merdeka Malang.

Fanger, P.O. (1970) Thermal Comfort, Danish Technical Press,Copenhagen

Lippsmeier, Gerg (1997) Bangunan Tropis. Alih Bahasa Indonesia Syahmir, N. Erlangga, Jakarta.

Purwanto, L.M.F. Kenyamanan Termal Pada Bangunan Kolonial Belanda Di Semarang DIMENSI TEKNIK ARSITEKTUR Vol. 32, No. 2,Desember 2004: 138 - 149 Jurusan Teknik Arsitektur, Fakultas Teknik Sipil dan Perencanaan - Universitas Kristen
Petra,

http://puslit.petra.ac.id/ puslit/journals/138

Prasetyo, Buddy (2003), Tesis Peranan Dinding dan Bukaan Dinding Masjid Agung Demak Terhadap Kondisi Termal Ruang Shalat Utama, Program Pascasarjana Magister Arsitektur Universitas Diponegoro. Semarang.

Rahim, Ramli dan Sanusi, Anwar (2007) Topologi, Morfologi dan Tipologi Masjid Tua di Sulawesi Selatan. Penerbit Jurusan Arsitektur Fakultas Teknik Universitas Hasanuddin.

Tahang, (2007). Tesis Kenyamanan Termal Ruang Shalat Masjid Raya Makassar, Program Pascasarjana Arsitektur Unhas, Makassar.

Talarosha, B. (2005) Menciptakan Kenyamanan Termal Dalam Bangunan, Jurnal Sistem Teknik Industri Volume 6, No. 3 Juli 2005, Universitas Sumatera Utara. 